\title{
Editorial
}

\section{Infeksi Covid-19 dalam Kehamilan}

\author{
Johanes C. Mose \\ Departemen Obstetri dan Ginekologi Fakultas Kedokteran Universitas Padjadjaran/ \\ RSUP Dr. Hasan Sadikin Bandung \\ Korespondensi:jcmose07@yahoo.com
}

Sejak kasus pertama infeksi Covid-19 dilaporkan dari propinsi Wuhan China pada 12 Desember 2019, penyakit ini sudah menyebar dengan sangat cepat dan menjadi pandemi ke hampir seluruh dunia termasuk di Indonesia.

Kasus infeksi Covid-19 pada ibu hamil juga semakin meningkat kejadiannya. Pelbagai laporan ilmiah membanjiri media sosial dan ilmiah di seluruh dunia tentang epidemiologi, gejala klinis, perjalanan penyakit, etiologi, patomekanisme molekuler dan seluler, upaya deteksi dini, diagnosis, pencegahan dan pengobatannya. ${ }^{1,2,3,4}$

Berbagai organisasi profesi kesehatan dunia menerbitkan serial panduan (guidelines) pengelolaan penyakit ini dalam kehamilan dari waktu ke waktu. ${ }^{5,67,7,8,9}$

Virus yang menyebabkan Covid-19 ini berasal dari golongan virus yang sama dengan virus penyebab SARS (severe acute respiratory syndrome) dan MERS (middle-east respiratory syndrome). Berdasarkan pengalaman kejadian yang lalu, ibu hamil dengan SARS atau MERS juga berisiko lebih tinggi mengalami keguguran atau melahirkan bayi prematur. Kejadian ini juga bisa terjadi pada ibu hamil dengan Covid-19, namun laporan kejadiannya masih sangat sedikit. $^{10}$

Siklus hidup SARS-CoV-2 di dalam sel inang (Gambar 1) dimulai pada saat protein $\mathrm{S}$ (spike protein) berikatan dengan reseptor ACE2 (angiotensin-converting enzyme-2). Ikatan ini akan menyebabkan bersatunya (fusi) viral envelope dengan membran sel melalui endosomal pathway. Kemudian SARS-CoV-2 akan melepaskan RNA ke dalam sel inang. Genome RNA kemudian di translasikan ke dalam replikasi poliprotein virus pp1a dan $1 a b$, yang kemudian terbagi-bagi menjadi produk yang kecil oleh enzim proteinase virus. Enzim polymerase akan menghasilkan rangkaian reaksi pemecahan subgenomik mRNA berulang-ulang melalui proses transkripsi dan akhirnya ditranslasikan menjadi protein virus tertentu. Protein virus dan genome RNA kemudian berubah menjadi virion didalam retikum endoplasma (ER) dan Golgi (ERGIC = Endoplasmic Reticulum-Golgi Intermediate Compartment), kemudian diangkut melalui vesikel dan dikeluarkan oleh sel. ${ }^{1}$

Sejauh ini, penularan utama virus Corona adalah melalui percikan air liur pada saat batuk atau bersin, namun semakin banyak bukti yang melaporkan adanya penularan melalui aerosol (airborne). Laporan kasus bayi baru lahir (dalam 12 jam pertama) dengan infeksi Covid-19 membuktikan kemungkinan adanya transmisi vertikal ibu-bayi yang intrauterin (melalui transplasenta) atau ekstrauterin (transvagina, transabdominal, atau melalui ASI ). Hal ini didukung oleh penelitian yang membuktikan adanya virus SARS-CoV-2 pada plasenta, cairan amnion, darah tali pusat dan ASI, bersamaan dengan adanya maternal viremia. ${ }^{10,11,12,13,14,15}$

Terlihat kecenderungan bahwa infeksi Covid-19 tidak memberi komplikasi yang berat pada kehamilan, sebaliknya kehamilan bukan faktor risiko terjadinya infeksi Covid-19. Pada umumnya ibu hamil dengan infeksi Covid-19 dengan infeksi yang berat tidak menunjukan perbedaan yang bermakna dengan kelompok kontrol. Kebanyakan (79\%) mereka tanpa gejala (asimptomatis). ${ }^{16}$ 


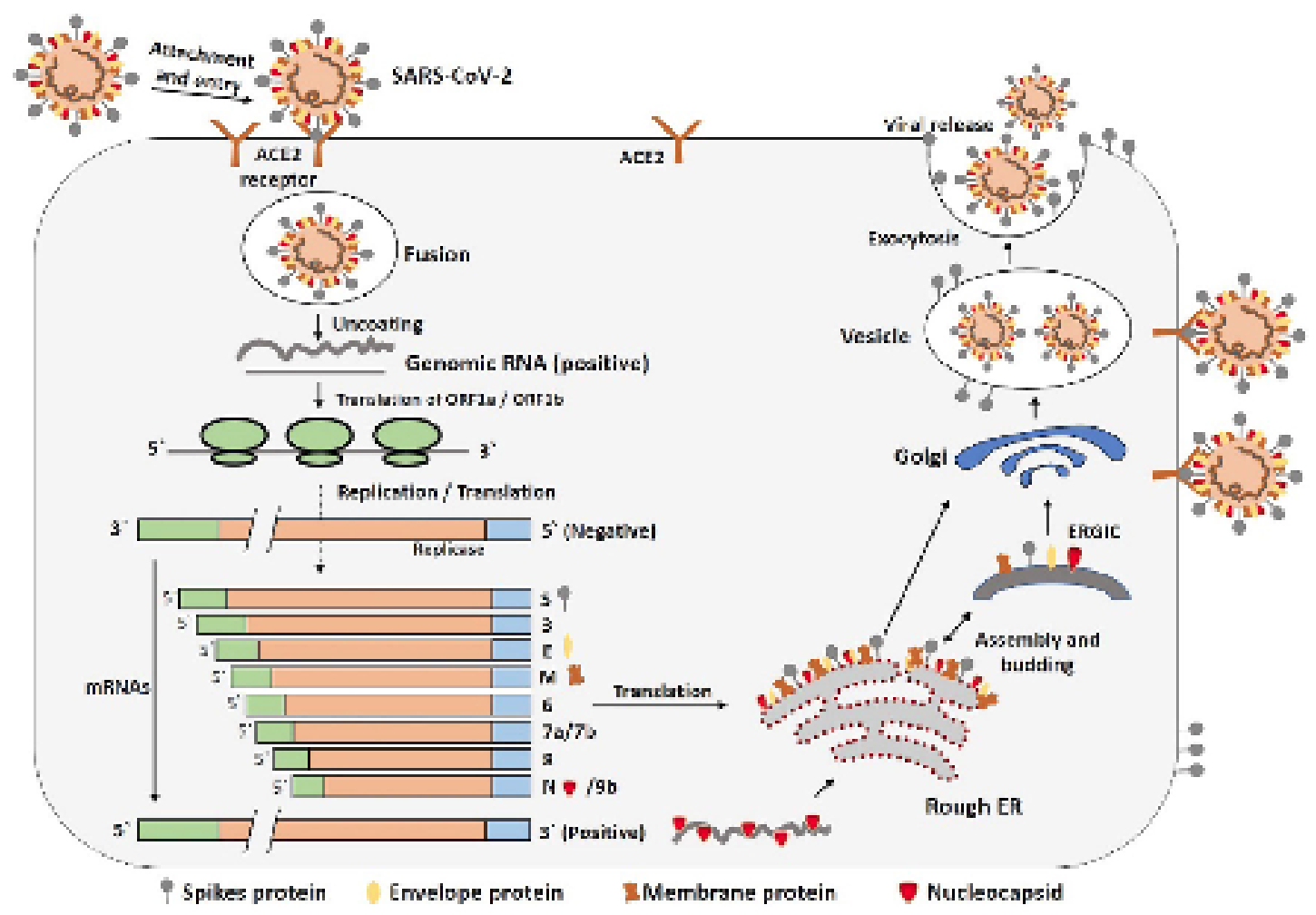

Gambar 1 Siklus hidup SARS-CV-2 dalam sel inang ${ }^{(1)}$

Ibu hamil dengan defisiensi Vitamin D, BMI $\geq 25 \mathrm{Kg} / \mathrm{m} 2$, Diabete Melitus berhubungan dengan tingginya kejadian infeksi Covid-19, oleh karena itu, semua ibu hamil dianjurkan untuk melakukan latihan olahraga yang teratur, diet sehat yang seimbang dan suplementasi vitamin D untuk mencegah kegemukan, DM tipe 2 dan defisiensi vitamin D. ${ }^{17,18}$

Sampai saat ini belum ditemukan data yang bermakna tentang hubungan infeksi Covid-19 dengan kejadian keguguran atau IUFD pada trimester II, namun $2 / 3$ dari kehamilan dengan Covid-19 disertai dengan kejadian PJT dan persalinan preterm. ${ }^{19,20}$

\section{Daftar Pustaka}

1. Shereen MA, Khan S, Kazmi A, Bashir N, Siddique R. Covid-19 infection: Origin, transmission, and characteristics of human coronavirus. J Advanced Reasearch 2020;24:91-98.

2. Boopathi S, Poma AB, Kolandaivel P. Novel 2019 coronavirus structure, mechanism of action, antiviral drug promises and rule out against its treatment. J Biomol Structure Dynamics (https://doi.org/10.1080/07391102.2020. 1758788)

3. Cascella M, Rajnik M, Cuomo A,
Dulebohn SC, Di Napoli R. Features, evaluation and treatment coronavirus (Covid-19). StatPearls(internet) 2020. (https://www.ncbi.nlm.nih.gov/sarscov-2/)

4. Park SE. Epidemiology, virology, and clinical features of severe acute respiratory syndrome-coronavirus-2 (SARS-CoV-2; Coronavirus Disease-19). Clin Exp Pediatr 2020.

5. Royal College of Obstetricians and Gynaecologists. Coronavirus (Covid-19) infection in pregnancy. Version II: Published Friday 24 July 2020.

6. Royal College of Obstetricians and 
Gynaecologists. Guidance for antenatal and postnatal services in the evolving coronavirus (Covid-19) pandemic. Version 2.2: Published Friday 10 July 2020.

7. Royal College of Obstetricians and Gynaecologists. Guidance for antenatal screening and ultrasound in pregnancy in the evolving coronavirus (Covid-19) pandemic. Version 1.1: Published Friday 10 July 2020.

8. Royal College of Obstetricians and Gynaecologists. Guidance for fetal medicine units (FMUs) in the evolving coronavirus (Covid-19) pandemic. Version 1.1: Published Friday 10 July 2020.

9. Royal College of Obstetricians and Gynaecologists. Guidance for maternal medicine services in the evolving coronavirus (Covid-19) pandemic. Version 2.4: Published Friday 10 July 2020.

10. Bergella V, Lockwood CJ, Barss VA. Coronavirus Disease 2019 (Covid-19): Pregnancy issues-UpToDate 2020.

11. Lamouroux A, Attie-Bitach T, Martinovic $\mathrm{J}$, et al. Evidence for and against vertical transmission for SARS-CoV-2 (COVID-19). Am J Obstet Gynecol 2020 doi: 10.1016/j. ajog.2020.04.039

12. Dong L, Tian J, He S, et al. Possible Vertical Transmission of SARSCoV-2 From an Infected Mother to Her Newborn. JAMA 2020 doi: 10.1001/ jama.2020.4621

13. Wang C, ZhouYH, Yang HX, et al. Intrauterine vertical transmission of SARS-CoV-2: what we know so far. Ultrasound Obstet Gynecol 2020;n/a(n/a) doi: 10.1002/uog.22045

14. Vivanti AJ, Vauloup-Fellous C, Prevot $\mathrm{S}$, et al. Transplacental transmission of SARS-CoV-2 infection. Nat Commun 2020;11(1):3572. doi: 10.1038/ s41467-020-17436-6
15. Walker KF, O’Donoghue K, Grace N, et al. Maternal transmission of SARS-COV-2 to the neonate, and possible routes for such transmission: A systematic review and critical analysis. . BJOG: Int J Obstet Gy 2020; Accepted Author Manuscript doi: 10.1111/147-0528.16362

16. Smith V, Seo D, Warty R, et al. Maternal and neonatal outcomes associated with COVID-19infection: A systematic review. PLOS ONE 2020;15(6):e0234187. doi: 10.1371/journal.pone.0234187

17. Grant WB, Lahore H, McDonnell SL, et al. Evidence that Vitamin D Supplementation Could Reduce Risk of Influenza and COVID-19 Infections and Deaths. Nutrients 2020;12(4):988. doi: 10.3390/ nu12040988 [published Online First: 2 April]

18. NHS Digital. Statistics on Obesity, Physical Activity and Diet, England 2020 [Available from: https:// digital.nhs. uk/data-and-information/publications/ statistical/statistics-on-obesity-physicalactivity-and- diet/england-2020/part3-adult-obesity-copy accessed 20 July 2020.

19. Zhang JP, Wang YH, Chen LN, et al. [Clinical analysis of pregnancy in second and third trimesters complicated severe acute respiratory syndrome]. Zhonghua Fu Chan Ke Za Zhi 2003;38(8):516-20.

20. Swartz D, Graham A. Potential Maternal and Infant Outcomes from Coronavirus 2019-nCoV (SARS-CoV-2) Infecting Pregnant Women: Lessons from SARS, MERS, and Other Human Coronavirus Infections.Viruses 2020:1-16. 